Fixed Point Theory, 21(2020), No. 1, 271-280

DOI: $10.24193 /$ fpt-ro.2020.1.19

http://www.math.ubbcluj.ro/ nodeacj/sfptcj.html

\title{
FIXED POINT THEOREMS FOR MULTIVALUED MAPPINGS ON BIPOLAR METRIC SPACES
}

\author{
ALİ MUTLU*, KÜBRA ÖZKAN** AND UTKU GÜRDAL*** \\ * Manisa Celal Bayar University, Department of Mathematics, 45140 Manisa, Turkey \\ E-mail: abgamutlu@gmail.com \\ ** Manisa Celal Bayar University, Department of Mathematics, 45140 Manisa, Turkey \\ E-mail: kubra.ozkan@hotmail.com or kubra.ozkan@cbu.edu.tr \\ Corresponding author \\ *** Mehmet Akif Ersoy University, Department of Mathematics, 15030 Burdur, Turkey \\ E-mail: utkugurdal@gmail.com
}

\begin{abstract}
In this article, we introduce concepts of Pompeiu-Hausdorff bipolar metric, multivalued covariant and contravariant contraction mappings in bipolar metric spaces. In addition to these, we express two main fixed point theorems, which are supported with four important corollaries, related to these multivalued mappings. Finally we give an example which presents the applicability of our obtained results.
\end{abstract}

Key Words and Phrases: Bipolar metric space, multivalued contraction, fixed point. 2010 Mathematics Subject Classification: 47H10, 54H25, 54E30.

\section{REFERENCES}

[1] E. Ameer, M. Arshad, W. Shatanawi, Common fixed point results for generalized $\alpha_{*}-\psi-$ contraction multivalued mappings in b-metric spaces, J. Fixed Point Theory Appl., 19(2017), no. 4, 3069-3086.

[2] I. Benedetti, S. Bolognini, A. Martellotti, Multivalued fixed point theorems without strong compactness via a generalization of midpoint convexity, Fixed Point Theory, 15(2014), no. 1, 3-22.

[3] P. Chaipunya, C. Mongkolkeha, W. Sintunavarat, P. Kumam, Fixed-point theorems for multivalued mappings in modular metric spaces, Abstr. Appl. Anal., 2012(2012), Art. ID 503504, 14 pages.

[4] H. Covitz, S.B. Nadler, Multi-valued contraction mappings in generalized metric spaces, Israel J. Math., 8(1970), no. 1, 5-11.

[5] P.Z. Daffer, H. Kaneko, Fixed points of generalized contractive multi-valued mappings, J. Math. Anal. Appl., 192(1995), 655-666.

[6] S. Dhompongsa, H. Yingtaweesittikul, Fixed points for multivalued mappings and the metric completeness, Fixed Point Theory Appl., 2009(2009), Art. ID 972395, 15 pages.

[7] D. Dorić, R. Lazović, Some Suzuki-type fixed point theorems for generalized multivalued mappings and applications, Fixed Point Theory Appl., 2011(2011), no. 1, doi:10.1186/1687-18122011-40.

[8] Y. Feng, S. Liu, Fixed point theorems for multi-valued contractive mappings and multi-valued Caristi type mappings, J. Math. Anal. Appl., 317(2006), no. 1, 103-112. 
[9] P.M. Fitzpatrick, W.V. Petryshyn, Fixed point theorems and the fixed point index for multivalued mappings in cones, J. London Math. Soc., 2(1975), no. 1, 75-85.

[10] O. Hadzic, Fixed point theorems for multivalued mappings in probabilistic metric spaces, Matematiki Vesnik, 3(1979), no. 66, 125-134.

[11] O. Hadzic, E. Pap, A fixed point theorem for multivalued mappings in probabilistic metric spaces and an application in fuzzy metric spaces, Fuzzy Sets and Systems, 127(2002), no. 3, 333-344.

[12] M. Khan, Common fixed point theorems for multivalued mappings, Pacific J. Math., 95(1981), no. $2,337-347$.

[13] D. Klim, D. Wardowski, Fixed point theorems for set-valued contractions in complete metric spaces, J. Math. Anal. Appl., 334(2007), no. 1, 132-139.

[14] N. Mizoguchi, W. Takahashi, Fixed point theorems for multivalued mappings on complete metric spaces, J. Math. Anal. Appl., 141(1989), 177-188.

[15] A. Mutlu, U. Gürdal, Bipolar metric spaces and some fixed point theorems, J. Nonlinear Sci. Appl., 9(2016), no. 9, 5362-5373.

[16] A. Mutlu, K. Özkan, U. Gürdal, Coupled fixed point theorems on bipolar metric spaces, Eur. J. Pure Appl. Math., 10(2017), no. 4, 655-667.

[17] B.S. Jr. Nadler, Multi-valued contraction mappings, Pacific J. Math., 30 (1969), no. 2, 475-488.

[18] A. Petruşel, I.A. Rus, Fixed point theory for multivalued operators on a set with two metrics, Fixed Point Theory, 8(2007), 97-104.

[19] A. Petruşel, I.A. Rus, M.A. Şerban, Basic problems of the metric fixed point theory and the relevance of a metric fixed point theorem for a multivalued operator, J. Nonlinear Convex Anal., 15(2014), 493-513.

[20] W. Sintunavarat, P. Kumam, Gregus-type common fixed point theorems for tangential multivalued mappings of integral type in metric spaces, Int. J. Math. Math. Sci., 2011 (2011), doi:10.1155/2011/923458.

[21] T. Suzuki, Mizoguchi-Takahashi's fixed point theorem is a real generalization of Nadler's, J. Math. Anal. Appl., 340(2008), 752-755.

[22] N. Tahat, H. Aydi, E. Karapinar, W. Shatanawi, Common fixed points for single-valued and multi-valued maps satisfying a generalized contraction in G-metric spaces, Fixed Point Theory Appl., 2012(2012), no. 1, doi:10.1186/1687-1812-2012-48.

Received: January 29, 2018; Accepted: June 7, 2018. 
